\title{
Barley Based Food Provide Consumers with Reliable, Healthy Food Choice
}

\author{
H.K. Pushpa and Dr.N.C. Varadacharyulu
}

\begin{abstract}
The wide range in sensory and functional properties offered by diverse Barley sources provides food manufacturers with unlimited product opportunities. Ayurveda has got three folds management and prevention of all disease Ahara (diet) Vihara (Exercise) and Ayushada (drug). Ahara is very important in our life for prevention of disease and promotion of health. Barley was used as food and medicinal purposes for promotion of health in ancient time. It is one of the most ancient and uses of yava cereals are described for religion ceremony dietary and medicinal preparation as pathya diet in various diseases including life style disorder in Ayurveda (Rahul Jain). The Food and Drug Administration (FDA) has announced that whole grain barley and barley containing food products may reduce cholesterol and lowdensity and Coronary Heart Disease(CHD).
\end{abstract}

The development of food products using whole grain barely, barely water and barely flour products have been formulated in food research laboratories. It has been used in human nutrition to improve nutritional health benefit. The food products such as biscuits, bread, crackers, cakes, desserts, malted soft drink, sauce, soup and Ice cream etc., by adding barley flour which has high content of $\beta$-Glucan.(Gary G)improves the immunity(Megan Ware) and alleviate the life style disorder. The development of food products using Barley flour fortification has increased and is attracting much attention from researchers for production of bakery products and pastries. This article focuses on fortification of barely food product with wheat based bakery product and its health benefit. Through this review of the paper understood that the It is excellent source of soluble and insoluble dietary fiber, the regular supplementation in our diet can reduces and alleviates the risk of some chronic diseases like coronary heart disease, Type II Diabetes and Cancer. And the sensory accepts also well with barley fortification food products.

Keywords--- Diet, $\beta$-glucan, Coronary Heart Disease, Fortification.

\section{INTRODUCTION}

(Hordeum vulgaris L.)Barley belongs to grass family, gramine( Ali Hafeez Malik) and is diploid self-pollinated crop (Chengdaoli)) It is one the three species of genus Hordeum belonging to tribe Triticeae of Poaceae family (Stephen B, 2000) It is an ancient cereals crop plant, and is also one of the most important cultivated cereal crops after wheat, maize,

H.K. Pushpa, Research Scholar, Jawaharlal Nehru Technological University, Ananthapur, A.P.

Dr.N.C. Varadacharyulu, Professor, Department of Biochemistry, Sri Krishnadevaraya University, Ananthapur, A.P.

DOI: 10.9756/IJRAS.8308 rice and is among the top ten crop and ranks $4^{\text {th }}$ crops in the world. (Akar et al. 2004).It's cultivation as domestic food crop started in the beginning of agriculture 10000 years ago (Mohammad).In India barley is used much as medicinal purpose not as regular diet. Yava is a common dhanya and traditional staple food in India (Ramesh Chandra Kumawat). It is mainly used as feed for animals and grain is also very important source for malt and food for human (Bhatty). Barley considered being most useful grain. As it is easily digestible compared wheat and other grain (Mohammad). But still it is remains underutilized as human food.

\section{Synonyms of Yava (Barley) in Ayurvedic Literature Sanskrit Name}

Medhya, Sitsuta, Divya, Dhanyaraja, Pavitradhanya, Akshta, Tikshna (Pandit Narahari) Properties Rasa: Kashaya, Madhura Guna: Rukshna, Laghu Virya: Sita Vipaka: Katu Doshakarma: Kaphapittahara (Susruta)

\section{Yava (Barley), Health Benefit and Utilization in Food}

Ayurveda has got three folds management and prevention of all disease viz., Ahara (diet) Vihara (Exercise) and Ayshada (drug). Ahara is very important in our life for prevention of disease and promotion of health. Proper selection of diet and diet plan plays a critical importance in disease management activities (Ramesh Chandra \&Kumawat). The Presence of the trace elements and the important pharmacological actions food has more health benefit(Ramesh Chandra \&Kumawat). Cerealsare nutritious. Regular consumption cereals likeyava (barley) and based products provide sufficient amount of nutrients needed for normal body function. It is one of the most ancient cereals in Ayurvedha (Rahul Jain). Yava is used for food and medicinal purpose in ancient time. In Ayurveda, theuses of yava are described for religion ceremony dietary and medicinal preparationas pathya diet in various diseases, and it is a well-balanced diet and efficient food to manage the life style disorders. (Rahul Jain).

They are good source of soluble and insoluble fiber; decrease the risk of chronic disease by decreasing the concentration of high cholesterol level in body (James M 2010) Carbohydrate plays an important part of normal Indian food. Barley rich in carbohydrate and also considered as lekhana means removes accumulated fat and toxins from the body effect (Kumar Rajesh) and reduces the risk of some chronic diseases likecoronary heart disease, Type II Diabetes and Cancer (Nirupam Ganguli).Consumption of barely based food several health benefits to alleviate the problems of life style disorders and Induction of body weight. $\beta$-Glucans promote the growth of beneficial microorganisms (Madhusweta Das). Barley water has antioxidants which 
prevent cell damage from free radicals it improve immunity, fight infection, intestinal infection and longevity (prevent ageing process). It is easily digested and helps with digestion of food. It improves immunity. Barley grains and Fenugreek seeds as potentially protective natural compound and treating against ulcer (Sati Al-dalain). Increased consumption of barely products should be considered as a dietary approach to reduce LDL cholesterol concentrations (Behall et al., 2004; Fadel et al.,).The major advantage of incorporating barley into various food products and their consumption stems from barley's potential health benefits. The effectiveness of barley b-glucans in barley food products in lowering blood cholesterol (Behall et al., 2004; Fadel et al., and glycemic index (Wood et al., 1990) Barley grain contains different phytochemical compounds (Mahesh) et al.,2010). It is excellent source of soluble and insoluble fiber (DF) and The chemical composition of the barley were more protein $(13.7 \mathrm{~g})$, fat ( 1.7 g) more than wheat (Madhavi Reddy) and other bioactive components such as Vitamins, minerals and phenolic compounds (Mahesh) Yava (Barley) can be a good supplier of protein, fibers and micronutrients in diet (Sridhar et al) It's effective remedy to avoid and manage the disease as well as control the lipidaemic index(Ramesh Chandra, et al). The health benefits of Dietary fiber (DF) capacity of lower the glycemic response of the food. The barley kashaya (Decoction) is the remedy for anti-cough, Bladder inflammation and Dermatitis (Mohammad). Barley bran and oat bran improves the histopathologyof kidney, liver, heart and lowering the lipid profile levels in hyper cholesterolemic rat (Haddad A.EI Rabey). Food product containing BBG should be considered an effective option for improving blood lipd (Keenan)

\section{Barley helps in Creating (prameha) Diabetics Free Society}

Diabetes mellitus is a serious global health problem. Especially Type II diabetes mellitus (T2DM) is increasing worldwide (Harold Bays) T2DM include those who are $45 \mathrm{yrs}$ old or more, have a family history of T2DM. This significantly affects quality of life and lifespan. (Valde Cekic). The yava (barley) is the remedy for reducing the risk for developing T2DM (Harold Bays). The ingredients of the barley, which produces lower glucoseand insulin levels, did not reduce spontaneous food intake over the reminder of the day (JB Keogh 2007). Food rich in DF release glucose more slowly in to the blood which is relevant to the prevention ofobesity and diabetes (Nugent 2005).Disease specific dietary measures are the unique concept of according to Acharya Charaka mentioned yava is the specific diet inprameha (Diabetes Mellitus). Yava should constitute the principal ingredient of food of the patient suffering from prameha. The important pharmacological actions of yava consumption, effect on carbohydrate metabolism. The role of micronutrients of (barley) in diabetic health has now turned out to be an effective mean to avoid as well as to control prameha (Sridar Reddy).

\section{Barely Based Food}

According to Food and Drug Administration (FDA) states 3 grams of barely $\beta$-Glucan per day a sufficient dietary intake to achieve decrease in serum total and low density lipoprotein cholesterol (Sullivan Petal). The importance in the application and the nutritional analysis of the BBG fractions was very successful in illustrating potential health benefits in foods. $\beta$ glucan shows promise in various food systems including beverages, meat products, and bakery products, ( Newman et al (1998) and in human nutrition, particularly where starch is a primary ingredient, like bread and pasta, noodles. [C.Brennan] Malt is the second largest use of barley. Among cereals, barley is most preferred for malt. $90 \%$ of malted barley is utilized for malting beer. Barley malt can be added to much food stuff such as biscuit, bread, cakes and desserts. [] Barley malt also can be substituted in to a lot of food stuffs such as biscuits, bread, crackers, cakes, desserts, malted soft drink, sauce, soup and Ice cream etc. [Taner Akar] BBG fiber fractions in foods and in human nutrition, particularly where starch is a primary ingredient bread and pasta(CBrennan) overall quality of the breadwas acceptable up to $40 \%$ barley flour fortification but harder and dark in colour (Basmanand Ko" ksel, 1999) but more acceptable 15-30\% barley flour and $20-30 \%$ barley flour prepared noodles are acceptable characteristics (Cheigh etal., 1976) up to $40 \%$ BF incorporated with wheat flour parotta enriched with dietary fiber and bglucan significantly increase water absorption and dough elasticity. 30\% is more acceptable characteristics compare to 40\% BF (G Koushika Maiya). Increases water absorption and dough elasticity, and decreases dough strength, extensibility and parotta-making characteristics of wheat flour. The $30 \%$ BF parotta showed increased contents of dietary fibre and bglucan by 2.0 and 10.5 times, $\beta$-Glucan rich parotta on a large scale by the baking industries.(G Koushika Maiya).

\section{CONCLUSION}

Barley is considered as a versatile food for good nutrition and health promotion in future. The Food Industries are increasing the production of nutrient value food products (Dominica). Yava is most ancient cereal with various active principles and properties such as vitamins, minerals, amino acids, antioxidant, $\beta$-glucan etc. Daily supplementation of Barley and Barley based food with 10 to $20 \%$ fortification products like biscuits, bread, cookies, Pasta, noodles, soups etc., should be used as food \&as medicinal preparation in any form in managing the life style disorders Diabetes, Hypercholesterolemia, Obesity and severe heart disease.

\section{REFERENCES}

[1] K.M. Behall, D.J. Scholfield and J. Hallfrisch, "Diets containing barley significantly reduce lipids in mildly hypercholesterolemic men and women", American Journal of Clinical Nutrition, Vol. 80, Pp.1185-1193, 2004.

[2] C Brennan, "Effects of $\beta$-glucan fractions from barley on structure, texture, sensory characteristics and nutritional value of processed cereal foods", HGCA project No. 2730, d Report No. 346, 2004.

[3] R.C. Kumawat, B. Chouhan, S. Rath and M. Kotecha, "Yava (Barley)-A Dietary Solution in Obesity", International Journal of Ayurvedic and Herbal Medicine, Vol. 3, No. 2, 2013.

[4] H.S. Cheigh, C.H. Ryu and T.W. Kwon, "Preparation and evaluation of driednoodles using barley-wheat and barley-soybean flours", Korean Journal of Food Science and Technology, Vol. 8, Pp. 236-241, 1976.

[5] J.G. Fadel, R.K. Newman, C.W. Newman and A.E. Barnes, "Hypocho lesterolemic effects of b-glucans in different barley diets fed to broiler chicks”, Nutrition Reports International, Vol. 35, Pp. 1049-1058. 
[6] Food and Drug Administration. http://www.fda.gov/ bs/topics/NEWS/ 2006/NEW01375.html

[7] Garry G. Hou and Veronica Jimenez, "Developing Barley-Fortified wheat Based Food”, Wheat Marketing Center, Portland.

[8] G. Koushika Maiya, B.G. Shwetha and D. Indrani, "Effect of barley flour on rheological characteristics of dough, organoleptic, nutritional and storage characteristics of south Indian parotta”, Science and Technology International, Vol. 21, No. 1, Pp. 24-32, 2013.

[9] Haddad A EI Rabey, Madeha N. AI-Seeni and Hanan M.Amer, "Efficiency of Barley Bran and Oat bran in Ameliorating Blood Lipid Profile and the Adverse Histological Changes in Hyper cholesterolemic Male Rats", Hindawi Publishing Corporation Bio Med Research International, 2013.

[10] Harlod Bays, Joy L Frestedt, Margie Belll and Carolyn, "Reduced the viscosity Barley $\beta$-glucan versus placebo a randomized controlled trial of the effects on insulin sensitivity for indiviuals at risk for diabetes mellitus”, Nutrition and Metabolism, 2011.

[11] J.M. Lattimer and M.D. Haub, "Effects of Dietary Fiber and Its Components on Metabolic Health”, Nutrients, Vol. 2, No. 12, Pp. 12661289, 2010

[12] J.B. Keogh, C.W.H. Lau, M. Noakes, J. Bowen and P.M. Clifton, "Effect of meals with high solulble fiber, high amylose barley variant on glucose, insulin, satiety and thermic effect of food in healthy lean women”, European Journal of Clinical Nurtriion, Vol. 61, Pp. 594-604, 2007.

[13] J.M. Keenan, M. Goulson, T. Shamliyan, N. Knutson, L. Kolberg and L. Curry, "The effect of BBG on blood lipid in a population of hyper cholesterolaemic men and women”, British Journal of Nutrition, Vol. 97, No. 6, Pp. 1162-1168, 2007.

[14] Kumar Rajesh and Kotecha Mita, "Physiochemical and Nutritional Evaluation of Yava (Hordeum Vulgare Linn”, International Research Journal of Pharmacy, Vol. 6, No. 1, 2015.

[15] G.N Mahesh and Abu-Ghannam, Barley for Brewing Characteristic changes during Malting, Brewing and Applications of its Reviews in Food Science and Food safety, 2010.

[16] Meghana Ware, "Barley: Health Benefits, Facts, Research Reviewed by University of Illinois-Chicago, School of Medicine", Nutrition/Diet Complementary Medicine/ alternative medicine, 2012.

[17] Mohammad, A Jabebor, Ali. Al_saadi and Russul Hikmat Behjet et al., "Characterisation and antimicrobial activity of barley grain (Hordeum Vulgare) extract”, International Journal of current Microbiology and Applied Sciences, Vol. 2 No. 8, Pp. 41-48, 2013.

[18] R.K. Newman, K.C. Ore, J. Abott and C.W. Newman, "Fibre enrichment of baked products with a barley milling fraction”, Cereal Foods World, Vol. 43, No. 1, Pp. 23-25, 1998

[19] Pandit Narahari, Rajanighantu. Tripathi Indradev, editor. 1st ed. "Varanasi: Chaukhamba Krishnadas Academy”, 2003, Susruta. Susruta Samhita. Ambika data Shastri, editor. 2nd ed. Varanasi; Chaukhambha Sanskrit Sansthan; 2009.

[20] R. Jain, P. Raghuwanshi and S.B. Patil, "Yava (Barley) - A key to the Life Style Disorder”, Ayupharm Int J Ayur, Vol. 2, No. 5 Pp. 138-143, 2013.

[21] S. Al-dalain, M. S El- kutty and H.S. Ibrahim, "Inhbitory Effect of Aquous Extract of Barley and Fenugreek on Ulcer Induction Rats", World Applied Sciences Journal, Vol. 5, No. 3, Pp. 332-339, 2008.

[22] Sridar Reddy, Ashok, Anand Katti and Shreevathsa, "Yava (Barley) The Disease Specific Diet in Prameha”, International Ayurvedic Medical Journal.

[23] S.S. AbuMweis, S. Jew and N.P. Ames, " $\beta$-glucan from barley and its lipid-Lowering capacity: a meta-analysis of randomized, controlled trial”, Europian Journal of Clinical Nutrition, Vol. 64, Pp. 1472-1480, 2010.

[24] P. Sullivan, E. Arendt and E. Gallagher, "The increasing use of Barley and barley by products in the production of healthier baked goods", Trends in Food Scince and Technol, Vol. 29, Pp. 124-134, 2013.

[25] Susruta, Susruta Samhita. Ambika data Shastri, editor. 2nd ed. Varanasi; Chaukhambha Sanskrit Sansthan, 2009.

[26] P.J. Wood, J.T. Braaten, F.W. Scott, D. Riedel and L.M. Poste, "Comparisons of viscous properties of oat and guar gum and the effects of these and oat bran on glycemic index", Journal of Agricultural and Food Chemistry, Vol. 38, Pp. 753-757, 1990.

[27] D. Zohary and M. Hopf, "Domestication of plants in the Old World: The Orgin and Spread of Cultivated Plants in West Asia, Europe, and the Nile Valley third ed”, Oxford University Press, 1990. 